Article

\title{
"Live Like a Lifelong Tourist"? The Contradicting Realities of Finnish Offshore Service Workers in Athens
}

\author{
Johanna Lilius $^{1, *}$ and Dimitris Balampanidis ${ }^{2}$ \\ ${ }^{1}$ Department of Architecture, Aalto University, 00076 Aalto, Finland; E-Mail: johanna.lilius@aalto.fi \\ 2 Department of Geography, Harokopio University, 17676 Kallithea, Greece; E-Mail: dbalaban@hua.gr \\ * Corresponding author
}

Submitted: 8 March 2020 | Accepted: 9 July 2020 | Published: 28 July 2020

\begin{abstract}
Contrasting the mass out-migration of the younger populace following the economic crisis in Greece and the simultaneous large inflow of refugees, the city of Athens has lately become an attractive place for tourists and lifestyle migrants. This article provides a better understanding of the marginal, yet unexplored in-migration of relatively affluent Europeans moving to Athens to work in the growing offshore service sector. Athens is an attractive place for offshore service work companies, as low salaries can be compensated for by "the sun," "Greek culture," and "low cost and high standard of living" (Bellos, 2019). Based on interviews with Finnish offshore workers, this article argues that the local context might not render all lifestyle migrants from wealthier countries similarly privileged. Due to their low salaries and recent changes in the local housing market fuelled by touristification, offshore service workers face a lack of affordable housing. The article further argues that affluent transnational migration is a multidimensional phenomenon, which needs to be contextualized, and which has nuanced, widespread effects on local housing markets and neighbourhood life.
\end{abstract}

\section{Keywords}

Athens; lifestyle migration; offshore service workers; touristification; transnational gentrification

\section{Issue}

This article is part of the issue "Urban Arrival Spaces: Social Co-Existence in Times of Changing Mobilities and Local Diversity" edited by Yvonne Franz (University of Vienna, Austria) and Heike Hanhörster (ILS-Research Institute for Regional and Urban Development, Germany).

(C) 2020 by the authors; licensee Cogitatio (Lisbon, Portugal). This article is licensed under a Creative Commons Attribution 4.0 International License (CC BY).

\section{Introduction}

As a historical phenomenon, migration is currently growing and diversifying. Residential tourism, second-home ownership, work-related multilocality, retirement migration, lifestyle migration, migration due to political unrest, as well as war, and poor economic opportunities; all these different kinds of voluntary and involuntary migration make people move around the globe and impact both the countries of origin as well as the destinations (e.g., Frauser, 2020; Ibrahim \& Tremblay, 2017; Salvati \& Benassi, 2020; Torkington, 2010; Williams \& Hall, 2000). This article investigates a specific small-scale migration movement, namely that of relatively affluent Northern
Europeans moving to Southern Europe in order to work in low-paid jobs. They represent a new, yet unexplored, class of transnational urban workers in Athens. Austerityridden Greece and Athens, in particular, have recently seen significant growth in multinational companies, offering offshored service work across Europe. Athens as a place becomes important in attracting these relatively affluent individuals to work with salaries that are not competitive compared to those in their countries of origin. Thus, workers are recruited by emphasising "the sun," "Greek culture," and "low cost and high standard of living" as a compensation for the comparatively low salaries (Bellos, 2019). Such features fit well into earlier conceptualizations of transnational mobilities from 
Northern to Southern Europe. Privileged lifestyle migrants above all desire the sunnier climates, the quality of life, and appreciate local lifestyles and "authentic" cultural experiences (Hayes, 2014, p. 1955).

At the local level, cities and neighbourhoods hosting migrants are often subjected to changes that affect the availability of local housing and local services, thus reshaping the identity and ultimately also restructuring the city culturally, socially, and spatially (e.g., Escobedo, 2020; Gunce, 2003). One of the major newspapers in Greece, I Kathimeri, claims that the activities of Teleperformance, the largest employer of offshore service workers in Athens, have led to "further demand for hospitality and nutrition services." It has been suggested that Teleperformance is "a good example of the positive impact that the establishment of businesses in Greece can have on the economy and the real estate market" (Bellos, 2019). Although this has not been verified by any systematic research, it does hint that offshore service workers might be used as lenses through which wider debates on transnational mobility, transnational lifestyles, and transnational gentrification can be followed. Building on the existing literature about privileged lifestyle migrants and their impacts on neighbourhoods, the article provides fresh insight into the kind of lifestyle-oriented mobilities that do not fully fit into usual North-South dichotomies. According to Novy (2018), there is need to understand mobility that does not fall into the more investigated and well-known types of privileged transnational migration, such as tourism or lifestyle migration, to grasp the implications that this place-consumption might have on neighbourhoods. This article aims to fill this research gap by specifically adopting a place-based perspective on Finnish offshore service workers, by exploring their everyday realities in Athenian neighbourhoods and by contrasting them with the conceptions and imaginaries built by their employers. It will further show that, although the motivations of the offshore service workers for leaving Finland are very similar to those of lifestyle migrants, their everyday life in Athens, because of the salaries and the demanding but yet mundane work, is not in line with existing accounts of the lifestyle of migrants originating from wealthier countries.

\section{Theoretical Debates}

The importance of Southern Europe as a major destination for Northern European tourists and a growing number of lifestyle migrants has been well acknowledged in the research literature (e.g., Jover \& Díaz-Parra, 2020). Tourism can be understood as the temporary travel or stay of people in destinations other than their usual residence (Ibrahim \& Tremblay, 2017). While the majority of people in the western world participate in touristic activities, lifestyle migration is a highly nuanced phenomenon. In general, lifestyle migrants are found to be highly mobile foreigners, of a variety of ages, primar- ily from middle- and upper-middle-class backgrounds. Typically, they seek a high(er) quality of everyday life by moving either temporarily or permanently to a different place (e.g., Benson \& Osbaldiston, 2014; Jover \& Díaz-Parra, 2019). Typically, lifestyle migrants approach migration as a form of consumption. This is the way they also distinguish themselves from other migration forms that are typically production-oriented (Benson \& O'Reilly, 2016, p. 22). Nevertheless, Ibrahim \& Tremblay (2017) claim that while lifestyle migration might be fuelled specifically by one category, the other may still have a secondary role in the process. Lifestyle migration has been documented both regarding the act of migration (where lifestyle migrants migrate, why, and how) and the lived experience following migration (Benson \& Osbaldiston, 2014), as well as geographical arbitrage (the act of relocating day-to-day expenses to low-cost locations to provide a higher quality of life; Hayes, 2014).

Lifestyle migrants include, for instance, retired people relocating to Southern European coastal areas or second-home owners to the countryside or to (often Southern European) cities. A new category of lifestyle migrants that have lately gained specific attention are digital nomads. According to Mancinelli (2020), digital nomads are individuals who take "advantage of portable computing technologies and widespread internet access," which allow them to "work remotely from any location and use this freedom to explore the world." In other words, they 'blend' tourism, leisure, and professional activities in a number of different places (Reichenberger, 2018). In Europe, students of higher education have also been strongly encouraged to make exchange stays for 5-10 months in another European country, increasing the number of young lifestyle migrants around the continent (Calvo, 2018, p. 2143). However, as stressed by Benson and Osbaldiston (2014, p. 3), "the ability to privilege lifestyle and realise it through migration is born out of relative affluence and privilege, and is thus inseparable from economic circumstance and global contexts of inequality in which it takes place."

Jover and Díaz-Parra (2019) have called for greater attention on the implications of these inequalities in urban processes. The impact of wealthy foreigners at the neighbourhood level has been specifically explored through the concepts of 'touristification' and 'transnational gentrification.' The so-called 'touristification' often occurs in neighbourhoods that have already been subjected to gentrification (Gravari-Barbas \& Guinand, 2017; Sequera \& Nofre, 2019; Wachsmuth \& Weisler, 2018). Gentrification as a process refers here to the production of space for progressively more affluent users (Hackworth, 2002). Gentrification then can be driven by a number of interplaying actors and processes. Touristification is typically driven by cities to attract investment and visitors, yet is further fuelled by arriving tourists, investors, and locals seeking income and profit from tourists. According to Novy (2018), the process of touristification affects neighbourhoods in two 
ways, which resemble those that have also been identified in gentrification literature. First of all, touristification changes the service supply of a neighbourhood to better fit the needs of tourists, meaning that the neighbourhood services used by locals are replaced by restaurants, cafés, and shops that usually attract tourists. Secondly, for the locals who stay in the area, touristification reduces their ability to access homes in their neighbourhoods; rented accommodation is often transformed into different kinds of-more profitable-accommodation for tourists (e.g., Jover \& Díaz-Parra, 2019; van Noorloos \& Steel, 2015). In particular, as many cities face the displacement of locals and a restructuring of the rental market, there is a growing body of research showing the impact of short-term rentals, widely known as Airbnb, on the local socio-economic context (e.g., Balampanidis, Maloutas, Papatzani, \& Pettas, 2019, in Athens; Davidson \& Infranca, 2016, in general; Llop, 2016, in Barcelona; Wachsmuth, Kerrigan, Chaney, \& Shillolo, 2017, in three Canadian cities).

According to Escobedo (2020, p. 6), tourists and lifestyle migrants with their similar use of neighbourhood spaces and similar consumption patterns particularly impact heritage spaces. These are typically historical neighbourhoods, which have often been neglected for long but which have recently actively been promoted as 'authentic' spaces by the cities. Thus, he claims that two processes, touristification and transnational gentrification, are apparent in historical neighbourhoods, as they "both operate through transnational movement of higher-income consumers of urban space" (Escobedo, 2020 , p. 6). Transnational gentrification describes new urban processes created by the transnational movement of people and investment from wealthier countries to lower-income communities. The term, coined by Sigler and Wachsmuth (2015), explains neighbourhood change caused by transnational investment in the housing market that especially meets the demand of transnational "gentry," such as lifestyle migrants, instead of locals. Thus, transnational gentrification is driven both by economic forces as well as the cultural practices and cosmopolitan ideals of privileged migrants such as lifestyle migrants and luxury tourists (Escobedo, 2020).

However, lifestyle migrants' appropriate local space on a more permanent basis than tourists. While lifestyle migrants might settle in the same neighbourhoods as tourists, their ties to the neighbourhood and the local residents are different (Jover \& Díaz-Parra, 2019). Yet, Torkington (2010), Eimermann and Kordel (2018), as well as Escobedo (2020) argue that, to date, little is known about the integration process and the local ties forged by international lifestyle migrants. Calvo (2018), for instance, recognizes Erasmus students in Lisbon as a new "class of transnational urban consumers." According to Calvo (2018), students not only take part in pre-existing local gentrification processes, but they are also active players in introducing their distinctive lifestyles into new local settings; they create new consumption spaces, ear- marking the neighbourhoods for colonialization by urban investors. This highlights the motivation of this study to understand why relatively affluent Finns leave Finland to work in low paid jobs in Athens, and how they integrate into their new neighbourhood and connect to touristic and leisure-related activities.

\section{Setting the Context: Athens, Migration, and Offshore Service Work}

In 2009, Greek society faced a debt-crisis which devastated the country economically and, in addition to that, evolved into a multi-faceted 'humanitarian crisis.' Unemployment rates, particularly among young and highly educated Greeks, rose dramatically and led thousands of people to migrate to Northern European countries and beyond. Only indicatively, the annual average unemployment rate in 2015 was nearly 25\%; for people aged between 25 and 29, it exceeded 37\%; and for those aged between 20 and 24, it rose to almost 50\%. Consequently, it is estimated by the Greek Statistical Authority that over half a million people left Greece during the period 2010-2014 (Labrianidis \& Pratsinakis, 2016; Pratsinakis, Hatziprokopiou, Grammatikas, \& Labrianidis, 2017). Concurrently, Greece has been-and still is-faced with a substantial inflow of refugees from the Middle East, Asia, and Africa, primarily from Syria, Afghanistan, Pakistan, Iraq, Turkey, and Iran. Refugees are now being added to the number of 'international immigrants' who had previously arrived and settled during the 1990s and early 2000s, primarily people from Albania and the remaining ex-Soviet and Balkan countries (Gropas \& Triandafyllidou, 2005). From 2013 until the present, the number of (registered) asylum seekers in Greece has increased to almost 300,000, following a rising trend every year (Greek Asylum Service, 2020).

In parallel with these developments, Greece has also experienced a so-called 'tourism miracle.' The number of tourist arrivals increased by $56 \%$ in only three years (2013-2016) and especially in Athens, which has recently and rapidly been transformed into an all-year 'city break' destination, not just a short-stay destination for those travelling to the Greek islands (Izyumova, 2017; Smith, 2016). Consequently, many central neighbourhoods of Athens have been faced with 'touristification' and its multiple effects, such as substantial changes in the real estate sector and, more precisely, the housing market (Balampanidis et al., 2019). Only indicatively, it is estimated that from 2016 to 2018, rent prices in central areas of Athens increased by almost 30\% (RE/MAX, 2016, 2017, 2018). At the same time, certain central neighbourhoods of the city transformed into quite mono-functional areas, dominated by leisure land uses and activities and, thus, attractive primarily to tourists rather than to permanent residents. Consequently, although not yet verified by research, it is reasonably assumed and expected that significant demographic changes will soon occur in central Athens, with 
many permanent residents being obliged to abandon their-until recently-attractive and affordable neighbourhoods. Such developments derive not only from the substantial increase of tourism, but also from the recently observed increase of 'lifestyle migration,' which is quite a new experience in the case of Athens. Tourist webpages (such as Greece-is.com and thisisathens.org) claim, for instance, that:

Athens is an increasingly attractive destination for the growing tribe of digital nomads, travelling the world with laptop in hand. It's not hard to see why. With a great climate, high-level cultural offering and low living costs, Athens makes sense as a base-for a few days or a few months-while you work remotely. (King, 2020)

On the neighbourhood level, this has been apparent since a number of co-working offices have been established in Athens (King, 2019). Furthermore, the Facebook group "Digital Nomads Athens" seems to imply the existence of this phenomenon in Athens. The group counts more than 2,500 members and its Instagram page has more than 4,000 followers. Apart from connecting people, these forums help digital nomads find apartments and workplaces, mostly in the central and coastal parts of the city.

During the last ten years, Athens has also seen a growth in migration related to offshore service work. Although research on offshore service work has been scarce in the past year, Richardson, Belt, and Neil (2000) claim that companies offering these services have been the most important single new source of employment in some less-favoured areas in Europe. For Teleperformance, a French multinational company, and the largest offshore service worker employer in Greece, locating to Athens has been a success story. It is one of the few companies in Greece that managed to increase the number of workers by more than 4,000 during the period 2014-2019 and to simultaneously double its turnover. This is an exceptional development in Greece (Bellos, 2019). Other similar but smaller players have also settled in Athens: Another French company called Webhelp opened their premises in Athens in 2016 and currently employs almost 400 workers speaking 17 different languages (Webhelp Greece, 2020). The largest Finnish online property management company established an office in Athens in 2015. Under the name Marou Creations, it offshored some of the service work and currently employs about 15 Finnish-speaking workers at its Athens premises. Call centres, according to Richardson et al. (2000, p. 358), are offices established to remotely deliver services over the phone. In the case of this study, offshore service work includes call centre services, online support, and social media facilitation. Call centres have been researched from a variety of perspectives, including their business models, organization of work, their impact on place and on the work- ing environment, and their meaning for local economies (e.g., Paulet, 2008). However, neither the lived experience of their workers nor their impact on place has gained any attention.

There is a clear intersection between tourism-related activities and recruiting employees to Athens, as also demonstrated by the title of this article. The title "Live Like a Lifelong Tourist" scrutinises the message of many of the relevant advertisements; it is about experiencing something new, not necessarily as a local, but rather as a temporary resident. The opportunities for productionoriented migration that the companies offer are presented as a form of place consumption (Novy, 2018). As in the description as to why digital nomads have found Athens described above, offshore service companies rely on "the sun," "Greek culture," and a "low cost and high standard of living" in order to attract Northern Europeans to low paid work in Athens (Bellos, 2019). For example, Randstad Hellas, which recruits European customer services workers suggests: "Would you like to live in a sunny country and experience the Southern European lifestyle?" (targeting Swedish natives; Randstad Hellas, 2019). Typical of the advertisements is their focus on the free-time that they would be able to enjoy in Athens, not the job per se: "You will...experience Greek music, taste great comfort food and visit their beautiful sights. Don't forget about their sandy beaches with crystal clear blue water and beautiful landscapes" (DK Global Recruitment, 2020). Similarly, as lifestyle migrants take advantage of the lower costs of living (often) to enhance or at least maintain their lifestyle in another (often sunnier) setting (e.g., Hayes, 2014), offshore service-companies also acknowledge the low cost of living as an advantage. Teleperformance, for instance, argues that one of the benefits for relocating in Athens is the availability of affordable housing: "While someone in the capital of Greece can rent an apartment at the price of $300 €$ in the city centre, the equivalent for Amsterdam would be 1,500€!" (Teleperformance, 2019).

\section{Methods}

This article focuses particularly on Finnish offshore service workers for several reasons. First, the interviewer is Finnish, and the phenomenon of the offshore workers was first noticed by the interviewer through job advertisements in the Facebook group "Finns in Athens." Furthermore, Finns in Greece and Athens have mainly been studied from a historical viewpoint as early 19th century adventurers and archaeologists, as well as through the daily lives of women who married Greeks (Järvinen-Tassopoulos, 2007). Secondly, and more importantly, being a Northern European country with a growing economy and low unemployment, offshore service workers migrating from Finland are unlikely to be motivated by financial need. The fact that Greece is the most popular holiday destination for Finns (Häkkilä, 2018) further suggests that the imaginaries of a tourist- 
related activity-filled life in Athens, presented by the advertisements for offshore service employees, have struck a chord.

In order to grasp the everyday realities of offshore service workers, in-depth semi-structured interviews were chosen as the basic research method. The sample of interviews provided the ability to understand the complexities and contradictions (Valentine, 2005) of the Finnish offshore service workers' locational decisions and everyday life in Athens. The sample for this study was quite small; therefore, it cannot be taken as being fully representative of the phenomenon under study. Nevertheless, although the background and ages of the respondents were diverse, they had some common features: Few had a higher education, most had not travelled much in their lives, and most of them originated from the countryside or small towns. A sample including respondents with different life trajectories and of different nationalities could give a more vivid picture of the everyday realities in Athens. Nevertheless, the sample offers the opportunity to analyse very detailed data and shed light upon a phenomenon that has not yet raised much research interest. The concept of reaching a data saturation point helped to define the point at which a sufficient number of interviews had been conducted to satisfactorily answer the research questions. In other words, when similar issues started being repeated, the data-gathering process was considered sufficient (Karisto, 2008). The respondents are presented in the Supplementary File.

The respondents were found through several Facebook pages, but mostly through the Facebook group called "Finns in Athens." The Facebook pages were found through searches on Facebook including keywords (in Finnish and English), such as 'Finnish,' 'Finns,' 'Athens,' 'flats,' 'offshore service work,' and 'Teleperformance.' Using Facebook as the basic source to find respondents excluded those who do not have a Facebook profile. Therefore, if the study had included respondents who were not on Facebook, more could have been learnt about the means of finding accommodation in Athens without using social media. The interviews were mainly held in cafés, typically in the neighbourhood where the respondent lived. Two interviews took place in the respondents' homes and one in the Nordic Library in Athens. Additionally, one interview took place in a café in the centre of Helsinki and one on Skype. The interviewer acknowledged the importance of being reflective of positionality and asymmetries of power in relation to the respondents (e.g., England, 1994; Jacobsson \& Åkerström, 2013). Therefore, at the beginning of the interviews, the respondents were told about the interviewer's own relationship to Athens, they were informed about how the data would be used, and how the academic publication process works. During the interviews, the participants were first asked about their housing and employment history, and about previous stays abroad. The second set of questions centred around their decision to relocate, and future plans related to mobility. Lastly, the interviewees were asked about their everyday life in Athens. In order to also gain a glimpse into the offshore service work from a Greek perspective, one current and one former Teleperformance worker were also briefly interviewed about their employment, the work, and the networks that they had formed through work. These respondents were found through the interviewer's personal networks. The interviews with the Finns each lasted approximately 40 minutes and all interviews were recorded. Notes were taken during the interviews and provided an index for the recordings, an 'open coding,' enabling the interviews to be transcribed when detail was needed. Following Weiss (1994), the interviews were first analysed based on the original themes of the interviews to find similarities and contradictions among the respondents. The themes were then linked to concepts and categories in the research literature.

In order to understand in which neighbourhoods landlords and transnational migrants operated in terms of housing, the study also included a read-through of the following Facebook groups: "Digital Nomads Athens," "Teleperformance: Moschato, Pireos Tavros, Kallithea," and "Teleperformance flats and roommates" during November 2019 and February 2020. During these months, the location of approximately 25 rental flat posts was analysed in terms of the neighbourhoods mentioned in the posts until data saturation was reached, that is, when the same neighbourhoods were repeatedly mentioned. The Teleperformance offices were also visited in February 2020 to understand if any particular services had been created around them.

\section{Relocating Abroad}

The climate in Greece was typically a pull-factor for the respondents, however, while the opportunity to spend time in a sunnier climate was important, their motivation had far more to do with gaining "cultural and personal experiences," and "a deeper sense of self": common motivations among digital nomads (Mancinelli, 2020) and most lifestyle migrants (Benson \& O'Reilly, 2009). The search for change (abroad) meant new work and new work-related challenges, breaking away from known routines, wanting to travel, or wanting to experience some adventure. Torkington has argued that the belief of lifestyle migrants that "change of residential place will lead not simply to better opportunities in life, but rather to something which might be described as a better lifestyle and/or more fulfilling way of life" (Torkington, 2010 , p. 102; emphasis in original) is a unifying factor among lifestyle migrants. In most cases, the decision to leave Finland had been simmering for a long time, with several respondents describing that they had undergone deep self-reflection and a rethink of their way of life and alternative modes of living before deciding to relocate. Many of the respondents expressed alienation from their everyday lives in Finland, which they wanted to break 
away from, despite reaching relatively good positions in Finland:

I had a really good salary, a good job that I loved....So, my reasons to relocate were really personal. My friends were having their second child, but I felt I could still try something and learn something new. (Respondent 7)

I was living my life on autopilot. We always tell ourselves: "Now is not a good moment" but, in the end, I found that if I don't fill my calendar myself, someone else will....You do so many things based on what you have learned, what your parents taught you, but then, while you are doing that trip, something changes inside you. I always felt I want to travel and live somewhere else, but then it hasn't been possible because of work. We always tell ourselves: "Now is not a good moment" but there is never a good moment. You have to take responsibility for your own life. (Respondent 3 )

Before leaving Finland, most of the respondents sold the majority of their belongings. What was left was often stored with relatives. They typically arrived in Athens with one suitcase, sometimes with only hand baggage. Their lifestyle choice resembled that of mobile teleworkers in which material accumulation, stability, and comfort are replaced by minimalism, uncertainty, and risk (Mancinelli, 2020). In this way, they differ from other lifestyle migrants such as Erasmus students or retirees, who typically maintain strong bonds to their country of origin, including a permanent address there. Nonetheless, only those who had reached a managerial position were planning to stay in Athens and with the current employer for a longer time. Others were planning either to return to Finland for better employment opportunities, better schools for their children, safety, family and friends, or to relocate somewhere else.

The fact that respondents ended up in Athens (or Greece to begin with) was somewhat down to chance. In this way, they differ from other lifestyle migrants who typically return as more permanent residents to a place they visited as tourists (Hayes, 2014). For Erasmus students, the selection of the city is a key element in the construction of the experience abroad, thus showing the importance of place-consumption in their mobility (Calvo, 2018 , p. 55). The respondents in this sample had been looking for work anywhere in Europe, mainly through the internet, while many repeated the same story; they sent applications to a number of countries and decided to accept the first job that they were offered.

\section{Finding a Home in Athens}

As the research literature (e.g., Calvo, 2018; Jover \& Diaz-Parra, 2019; Torkington, 2010) has demonstrated, lifestyle migrants from wealthier countries typically behave in similar ways. They do not speak the local language, they wear similar clothes, and they originate from similar places. It is also typical that they share similar spatial patterns: They are attracted to the same neighbourhoods, often located in city centres, they consume the same goods, and they induce profound changes in these neighbourhoods. Considering the body of literature discussing the way that tourists and lifestyle migrants participate in restructuring urban developments and housing markets (e.g., Escobedo, 2020; Gravari-Barbas \& Guinand, 2017; Jover \& DíazParra, 2019; Sequera \& Nofre, 2019; Sigler \& Wachsmuth, 2015; Wachsmuth \& Weisler, 2018), it is also worth considering how and where offshore service workers find their homes. Offshore service workers often arrive in Athens with a relocation package provided by their employer, including flight tickets and a two-week stay in a hotel. This affords the workers some time to find an apartment upon arrival; as with some other lifestyle migrants, existing ex-pat networks are important in terms of finding housing (van Noorloos \& Steel, 2015). Teleperformance offered some help to find a home through real estate agents, but it was repeated during many of the interviews that it was not of much help: The competition was simply too high. Thus, flats and rooms were found through other Teleperformance workers, through Airbnb, and via two Greek real estate websites, as well as a variety of Facebook groups. The Facebook groups "Teleperformance: Moschato, Pireos Tavros, Kallithea" (178 members) and "Teleperformance flats and roommates" (more than 3,000 members) are very active, with posts from landlords, real estate agents, and people looking for roommates. According to the Greek newspaper I Kathimeri, in addition to being a major employer, Teleperformance also generates a demand for rental apartments. Consequently, there is a lack of available housing in neighbourhoods close to its offices (Bellos, 2019). Most of the posts in the two Facebook groups would support this argument, as the majority of the flats posted are located in such neighbourhoods. The lack of housing was also emphasized by the respondents. Those who had stayed longer in Athens had typically found a place to stay more easily than those who arrived in 2019-2020. There was also uncertainty as to whether it was beneficial to be known as a Teleperformance worker looking for housing. Those who had stayed longer in Athens typically emphasized that Teleperformance workers were considered to be reliable tenants. However, several respondents also told of cases when especially very young Teleperformance workers left suddenly, leaving their rent unpaid. This had-to some extent-damaged the reputation of the newcomers, as one respondent emphasized:

I now prefer to say I work fulltime, not that I work for Teleperformance. (Respondent 8)

This respondent had left a fairly good job in Finland and her own home and was struggling to find a flat. If 
she had been able to afford it, she would have gladly stayed in the central neighbourhoods, but she had lowered her expectations and just wanted to find a decent affordable home of her own. She and another respondent mentioned that some landlords highlight in their apartment advertisements that they do not rent it to Teleperformance workers. This seemed to be a new phenomenon and may be related to the overall recovery of the economy which may allow landlords to be more selective. Flat-sharing is a phenomenon mostly connected to students, but it is also a new way of living as a response to increasingly precarious economic conditions (Tegan, Bergan, Gorman-Murray, \& Power, 2020). While many of the respondents had hoped to find a place of their own, many shared flats, typically with other Teleperformance workers.

Regarding housing issues, different mobilities seemed to overlap and also interplay (Novy, 2018, p. 434). In Athens, touristification and the expansion of the Airbnb market, as well as increasing (foreign) investment in real estate property, have led to a significant lack of affordable housing, with rents in many areas now being at levels that neither local nor offshore service workers can afford to pay. Indicatively, during the period 2016-2018, rent prices increased on average by almost $15 \%$ across the whole region of Athens and, more precisely, by $20 \%, 26 \%$, and $30 \%$ in the southern, western, and central areas, respectively (RE/MAX, 2016, 2017, 2018). Almost all the respondents mentioned that the rents had recently increased significantly:

It is really in the air now the discussion about rising rents. (Respondent 8)

Everyone is horrified because salaries are not keeping up with the increasing rents. (Respondent 4)

It's becoming impossible....Average-income people can't afford the rents in better locations anymore. (Respondent 7)

Most of the respondents talked about Airbnb hiking up rents and also noticed that rents in the previous years had been very low in comparison to other European cities. This would indicate transnational gentrification, and the argument put forward by Sigler and Wachsmuth (2015) that mobility creates new possibilities for housing investment also in Athens, as there is a growing demand for housing by non-locals who can pay higher rents. However, transnational gentrification in Athens may not be solely connected to leisure-driven migration, but also to other forms of migration, such as that of offshore service workers. This makes the effects of transnational gentrification more widespread, as more neighbourhoods in different locations become attractive for investment, not only those in touristic destinations. Nevertheless, there was some doubt as to whether Athens would be able to continue competing for workers with its current salaries and the rising rents: "Soon, they won't get anyone here anymore" (Respondent 8). The investments by foreigners were also prevalent in the sample as almost half of the respondents were renting from a foreign landlord, and many had rented several flats from fellow foreigners including Chinese, Spaniards, Israelis, and French.

\section{Everyday Life in the Neighbourhood}

Multi-local (transnational) practices become specifically visible at the level of the neighbourhood. Apart from changing the housing market dynamics, migrants also challenge social co-existence. While it has been emphasized that tourists and lifestyle migrants contribute to processes of gentrification, how did the everyday life of respondents look like at the neighbourhood level?

As already mentioned, few of the respondents had settled in the tourist neighbourhoods of Athens. This was related to the rent prices, which were inaccessible to those on Teleperformance salaries. Therefore, the location criteria for the respondents were related to accessibility to work as well as to safety. Considering the large-scale employment that companies such as Teleperformance offer, it is important where these companies locate. Their workers are highly dependent on public transport and housing in connection with these places.

Most respondents expressed a feeling of attachment to their neighbourhood: A place for everyday activities such as buying groceries, going to the gym, or going for a daily run. In Athens, a large number of small businesses closed down during the crisis, but a significant number of new (different) businesses have also opened up during the last few years. They have been mainly lowcost and accessible businesses, such as coffee shops and restaurants or, more generally, catering and leisure businesses (Belavilas \& Prentou, 2015). This has to do with the low average incomes in Greece, which do not support the consumption of expensive services and goods. In any case, new local businesses were found to be frequented not only by locals but also by the offshore service workers, who often bought a coffee to go or ordered food. Nevertheless, it seems unlikely that the presence of offshore service workers has somehow contributed to the closedown and/or displacement of older local businesses, as happened in the case of lifestyle migrants in other countries (Jover \& Díaz-Parra, 2020). Greece is often emphasized as a particularly suitable touristic destination because of its food culture, but interestingly, the respondents were not especially keen on Greek food. In fact, some expressed that they would have liked a better variety of cuisine in their neighbourhood. This kind of supply has become available in some of the gentrified central neighbourhoods of Athens, as well as in the less central and multi-ethnic neighbourhoods. Those respondents who lived in multi-ethnic neighbourhoods, typically really appreciated the ethnic grocery stores in the area. 
According to Meier (2014, p. 9), migrant professionals typically learn about new cities through inclusion in specific social networks and organizations of migrant professionals. Likewise, Erasmus students typically spend their everyday lives primarily among their peers (Calvo, 2018). This also seemed true for the offshore service workers, the workplace being the most important source of social networks among Teleperformance workers. A few respondents had no Greek friends; nevertheless, some were interested to get to know Greeks, although an older respondent, who worked for a small Finnish company, and thus did not have many colleagues, emphasised that there were not many opportunities to do so:

It's not so easy to get to know them. They tend to sit together in cafés and bars. (Respondent 2)

Some of the respondents had found partners in Greece but only one had a Greek partner; the others had partnered either with non-western migrants or a Greek with an immigrant background. Only three of the respondents knew Greek, while some were learning, and some knew basic Greek. The interest in learning at least basic Greek stemmed out of the need to be polite and show respect. At the same time, it was emphasized how well Greeks speak English compared to many other Southern European countries:

Here you can really get by $100 \%$ in English, that really surprised me compared to other countries. (Respondent 4)

This respondent had spent a longer period in Spain, where the lack of a common language had been an obstacle for closer contact with locals. English enabled social contact and encounters in the neighbourhood as the respondents could easily briefly chat in shops, kiosks, and with taxi drivers. The small shops in which the salespeople had quickly started to recognise their customers and where it was easy to have a quick chat were important to many of the respondents:

Sometimes I stay and talk in the kiosks for half an hour. (Respondent 5)

This reflected a general stance brought up by many, that the informal relationships built in the neighbourhood were something worth mentioning, perhaps because they are not so usual within the Finnish context. All respondents said that they greeted their neighbours, while a few also slightly knew their neighbours. This is consistent with earlier research findings that show that relationships (between Greeks and immigrants) in the city's neighbourhoods, but also within the same residential buildings vary, and, more precisely, cover the whole spectrum of interethnic relationships from (formal or close) relationships of neighbouring, friendship, mutual help, and solidarity to relationships of alienation, distance, rejection, and racism (e.g., Balampanidis \& Bourlessas, 2018). One of the respondents was living in the same building as his landlord, who would make an effort to make his tenants feel welcome. Another respondent told of a local who had helped him get accustomed to Greece:

The guy next door has lived in the same building his whole life, and now he is around 45-50. He has really shared things with me about Greek culture. (Respondent 5)

Based on the descriptions of the respondents, the neighbourhood was an important place in which to explore and experience Athens, both as a multi-ethnic place and as a place of Athenian neighbourhood life. Nevertheless, the narrations reflected an ordinary everyday life rather than one of touristic experience.

\section{Live Like a Lifelong Tourist?}

While the article has demonstrated some similarities in the motivations for mobility between lifestyle migrants and the offshore service workers, there were differences in the ways that their everyday lives played out in the new location. This has to do with the neighbourhoods they stayed in, as the article has shown, but also with the character of the work that they do abroad. Earlier research has demonstrated that call-centre work is typically considered to be highly routinized and under strict surveillance (e.g., Richardson \& Belt, 2001). In this way, it differs significantly from the work of digital nomads. According to Reichenberger (2018), digital nomads perceive work as another leisure activity that is both motivating and fulfilling. The offshore service workers talked about the strict working hours, strict timing of breaks, and the rules prohibiting them from having their mobiles or even paper and pens with them at their desks. Moreover, many emphasized the lack of challenge in the work. It was clear that the work provided an opportunity to make a living abroad. The paradox between looking for personal freedom and a lifestyle change alongside the strict routines of the work, particularly at Teleperformance, often resulted in only short periods of employment being sustained. This particular company had typically offered a three-month contract, to begin with, with some ending their contract after this and some only continuing with one more three-month contract before leaving. For others, though the opportunity provided by Teleperformance was important in their current economic situation, and it was a means to an end of staying in Athens and Greece, especially for those who had partners in Athens.

The job advertisements for the offshore workers emphasized the various opportunities for free-time activities and for participating in touristic activities. However, the daily lives of the respondents of this sample mainly revolved around work. The majority worked from 
09:00 a.m. to 05:00 p.m., consequently spending their day between the office and their home in the neighbourhood. They emphasized that they had very little energy after work to pursue anything:

It's tough to do work on the computer for eight hours per day. Often in the evening, you do not have the energy to do much more. (Respondent 1)

This respondent had also worked in customer service in Finland, so he was used to the nature of the work, but preferred spending his evenings at home, ordering takeaways, and going jogging in the neighbourhood. The everyday lives of the respondents did not appear touristic because of the lack of time and energy, with most of their free time being spent in the (non-touristic) neighbourhoods. Visiting and spending time in the historical city centre and the historical sites was not the reason for them to be in Athens (as could be expected in the case of tourists), nor did it play a specific role in their everyday life. Nevertheless, when asked about their favourite place in Athens, many mentioned places around the historical city centre. Similarly, to what could be expected from the locals, the respondents did not visit the city centre on a daily or even weekly basis.

During the weekends, some tourism-related activities, such as sightseeing, did occur. Some respondents had visited the nearby island of Aegina and seen some of the important ancient sights in the centre of Athens. Some had also visited the beaches of Athens once or twice. However, these were activities optional to just relaxing and hanging around with peers. For most of the respondents, another obstacle to living like a tourist was the lack of money, deriving from low salaries:

After taxes and rent, I'm not left with a lot of money. I have to really count my pennies. (Respondent 8)

\section{Conclusion}

This article has shed light upon the still marginal, but growing and yet unexplored group of transnational migrants from wealthier countries relocating for lowincome jobs in popular tourist destinations. It has claimed that, although lifestyle consumption through locality was used as a means to render low-paid offshore service work attractive to employees from wealthier regions, the imaginary of Athens as a lifestyle destination was not an important reason for Finnish employees to relocate. The locational decision was rather driven by the availability of low-threshold employment, that is, temporary employment offered without specific requirements for education or work experience. Lowthreshold employment enables those who are typically unable to engage in remote work to have a lifestyle involving work-based migration experiences. As such, this article has broadened the understanding of lifestyle migration, showing that the offer of low-threshold work is also significant for enabling lifestyle migration. The promise of living like a lifelong tourist, as suggested by the advertisements of offshore service work employers, was not fulfilled in the everyday life of these workers. Nonetheless, although the aspirations and motivations of lifestyle migrants from wealthier countries to Southern Europe may be similar, the salaries and working conditions of the offshore service workers became a factor distinguishing them from other lifestyle migrants. They neither had the freedom, energy, nor the money to live like tourists in Athens. While the Finnish offshore workers drew higher salaries than their Greek colleagues, their relative privilege in terms of income played out differently than that of other lifestyle migrants in the housing market. The increasing rents, due to processes of touristification and transnational gentrification, hindered the Finnish offshore service workers from accessing the same neighbourhoods as other migrants from wealthier countries. An interesting question is why so many respondents mentioned the difficulty of finding housing, especially as Teleperformance workers: the largest offshore service company. It would suggest that the rental market in Athens is becoming differentiated even among privileged and relatively privileged $\mathrm{mi}-$ grants, as suggested by Jover and Díaz-Parra (2020) also in the case of Seville, Spain.

Although the respondents did use local businesses such as cafés and restaurants, there was no evidence indicating that these practices have displaced businesses used foremost by locals or contributed to any process of major or violent neighbourhood change. Rather, many local businesses in Athens had already disappeared as a consequence of the economic crisis. Neither did we find evidence that local businesses had specifically addressed lifestyle migrants, a process well acknowledged in the case of neighbourhood touristification (e.g., Sequera \& Nofre, 2019). The article nevertheless showed that cafés, restaurants, grocery, and convenience stores were significant for the offshore service workers in terms of building local ties in the neighbourhood. They were typically the places were the respondents had contact with the locals. This way, the article has contributed to an understanding of the integration processes and how international lifestyle migrants' local ties are developed, as requested by Torkington (2010), Eimermann and Kordel (2018), and Escobedo (2020).

As the article has demonstrated, the locational decisions of large offshore service work companies impact local urban development, putting pressure on infrastructure, such as public transportation, housing, and the availability of spaces of consumption. It also creates prospects for transnational gentrification (Sigler \& Wachsmuth, 2015) in non-touristic neighbourhoods, as it generates new demand for rental housing from migrants with potentially higher incomes than the locals. Thus, the effects of transnational gentrification become more widespread in the city. It has been shown here that offshore service workers in Athens, with their lower in- 
comes and different consumption patterns, differ from the gentry typically connected to transnational gentrification such as privileged lifestyle migrants and luxury tourists (Escobedo, 2020). For those northerners who lack the educational and financial privilege that other lifestyle migrants carry, offshore service work creates possibilities to move abroad, experience something new, build relationships, and attach to touristic cities such as Athens. Overall, transnational migration flows between Northern and Southern Europe prove to be rather ambiguous, diverse, and multidimensional, and above all they are dependent on the very specific local context.

\section{Acknowledgments}

The authors would like to thank Haris Litos for helping with Greek newspaper articles, the anonymous reviewers and the editors in particular for valuable comments and suggestions on how to improve the previous drafts.

\section{Conflict of Interests}

The authors declare no conflict of interests.

\section{Supplementary Material}

Supplementary material for this article is available online in the format provided by the author (unedited).

\section{References}

Balampanidis, D., \& Bourlessas, P. (2018). Ambiguities of vertical multi-ethnic coexistence in the city of Athens: Living together but unequally between conflicts and encounters. In R. van Kempen, S. Oosterlynck, \& G. Verschraegen (Eds.), Divercities: Understanding super-diversity in deprived and mixed neighbourhoods (pp. 165-186). Bristol: Policy Press.

Balampanidis, D., Maloutas, T., Papatzani, E., \& Pettas, D. (2019). Informal urban regeneration as a way out of the crisis? Airbnb in Athens and its effects on space and society. Urban Research \& Practice. Advance online publication. https://doi.org/10.1080/17535069. 2019.1600009

Belavilas, N., \& Prentou, P. (2015). Abandoned buildings and vacant shops: The spatial pattern of the crisis. Athens Social Atlas. Retrieved from https://www. athenssocialatlas.gr/en/article/vacant-shops

Bellos, I. (2019, March 4). The call center of Apple is located in Athens. I Kathimerini. Retrieved from https://www.kathimerini.gr/1012776/article/ oikonomia/epixeirhseis/to-thlefwniko-kentro-thsapple- $\bigvee$-vrisketai-sthn-a8hna

Benson, M., \& O'Reilly, K. (2009). Migration and the search for a better way of life: A critical exploration of lifestyle migration. The Sociological Review, 57(4), 608-625. https://doi.org/10.1111\%2Fj.1467954X.2009.01864.x
Benson, M., \& O’Reilly, K. (2016). From lifestyle migration to lifestyle in migration: Categories, concepts and ways of thinking. Migration Studies, 4(1), 20-37. https://doi:10.1093/migration/mnv015

Benson, M., \& Osbaldiston, M. (2014). New horizons in lifestyle migration research: Theorising movement, settlement and the search for a better way of life. In M. Benson \& M. Osbaldiston (Eds.), Understanding lifestyle migration: Theoretical approaches to migration and the quest for a better way of life (pp. 1-33). New York, NY: Palgrave Macmillan.

Calvo, D. M. (2018). Understanding international students beyond studentification: A new class of transnational urban consumers. The example of Erasmus students in Lisbon (Portugal). Urban Studies, 55(10), 2142-2158. https://doi.org/10.1177/ 0042098017708089

Davidson, N. M., \& Infranca, J. J. (2016). The sharing economy as an urban phenomenon. Yale Law \& Policy Review, 34(2), 216-262.

DK Global Recruitment. (2020). Job advertisement by DK Global Recruitment. Multilingualvacancies. Retrieved from https://www.multilingualvacancies. com/dk-global-recruitment-jobs

Eimermann, M., \& Kordel, S. (2018). International lifestyle migrant entrepreneurs in two new immigration destinations: Understanding their evolving mix of embeddedness. Journal of Rural Studies, 64, 241-252. https://doi.org/10.1016/j.jrurstud. 2018.04.007

England, K. V. L. (1994). Getting personal: Reflexivity, positionality, and feminist research. The Professional Geographer, 46(1), 80-89. https://doi.org/10.1111/ j.0033-0124.1994.00080.x

Escobedo, D. N. (2020). Foreigners as gentrifiers and tourists in a Mexican historic district. Urban Studies. Advance online publication. https://doi.org/ 10.1177/0042098019896532

Frauser, M. (2020). Migrant citizenship, privileged local belonging and the option to return: Germans on the Turkish coast. Comparative Migration Studies, 8(7). https://doi.org/10.1186/s40878-019-0155-1

Gravari-Barbas, M., \& Guinand, S. (Eds.). (2017). Tourism and gentrification in contemporary metropolises: International perspectives. Abingdon: Routledge.

Greek Asylum Service. (2020). Statistical data of the Greek asylum service. Athens: Greek Asylum Service. Retrieved from http://asylo.gov.gr/en/wp-content/ uploads/2020/02/Greek_Asylum_Service_data_ January_2020_en.pdf

Gropas, R., \& Triandafyllidou, A. (2005). Migration in Greece at a glance. Athens: Hellenic Foundation for European \& Foreign Policy.

Gunce, E. (2003). Tourism and local attitudes in Girne, Northern Cyprus. Cities, 20(3), 181-195. https://doi.org/10.1016/S0264-2751(03)00012-X

Hackworth, J. (2002). Post-recession gentrification in New York city. Urban Affairs Review, 37, 815-843. 
Häkkilä, T. (2018, April 13). Nämä ovat suomalaisten suosikkilomakohteet-trendikäs saari nousemassa kestosuosikiksi [These are the favorite holidays of Finns: A trendy island is becoming an all-time favorite]. Ilta Sanomat. Retrieved from https://www.is. fi/matkat/art-2000005640327.html

Ibrahim, Z., \& Tremblay, R. (2017). Lifestyle migration and the quest for a life-long vacation. Téoros, 36(2). Retrieved from http://journals.openedition. org/teoros/3074

Izyumova, E. (2017). The hospitality sector in Athens over the years. Hospitality Net. Retrieved from https:// www.hospitalitynet.org/opinion/4086010.html

Jacobsson, K., \& Åkerström, M. (2013). Interviewees with an agenda: Learning from a 'failed' interview. Qualitative Research, 13(6), 717-734. https://doi.org/ $10.1177 / 1468794112465631$

Järvinen-Tassopoulos, J. (2007). Suomalaisena naisena Kreikassa [Being a Finnish woman in Greece]. Helsinki: Minerva Kustannus.

Jover, J., \& Díaz-Parra, I. (2019). Gentrification, transnational gentrification and touristification in Seville, Spain. Urban Studies. Advance online publication. https://doi.org/10.1177/0042098019857585

Jover, J., \& Díaz-Parra, I. (2020). Who is the city for? Overtourism, lifestyle migration and social sustainability. Tourism Geographies. Advance online publication. https://doi.org/10.1080/14616688.2020.1713878

Karisto, A. (2008). Satumaa: Suomalaiseläkeläiset Espanjan Aurinkorannalla [Finnish retirees at the sunny coast of Spain]. Helsinki: Suomalaisen Kirjallisuuden Seura.

King, A. (2019). Athens as a destination for digital nomads and startuppers. Greece Is. Retrieved from https://www.greece-is.com/athens-as-a-destination -for-digital-nomads-and-startuppers

King, A. (2020). Where to take your laptop for coffee in Athens. This is Athens. Retrieved from https:// www.thisisathens.org/activities/urban-culture/ internet-cafes-digital-nomads

Labrianidis, L., \& Pratsinakis, M. (2016). Greece's new emigration at times of crisis (GreeSE Paper No. 99). London: Hellenic Observatory. Retrieved from http:// eprints.Ise.ac.uk/66811/1/GreeSE-No.99.pdf

Llop, N. L. (2016). A policy approach to the impact of tourist dwellings in condominiums and neighborhoods in Barcelona. Urban Research and Practice, 10(1), 120-129. https://doi.org/10.1080/17535069. 2017.1250522

Mancinelli, F. (2020). Digital nomads: Freedom, responsibility and the neoliberal order. Information Technology \& Tourism. Advance online publication. https:// doi.org/10.1007/s40558-020-00174-2

Meier, L. (2014). Introduction: Local lives, work and social identities of migrant professionals in the city. In L. Meier (Ed.), Migrant professionals in the city (pp. 1-20). London and New York, NY: Routledge.

Novy, J. (2018). 'Destination' Berlin revisited. From (new) tourism towards a pentagon of mobility and place consumption. Tourism Geographies, 20(3), 418-442. https://doi.,org/10.1080/14616688.2017.1357142

Paulet, R. (2008). Location matters: The impact of place on call centres. Journal of Industrial Relations, 50(2), 305-318. https://doi.org/10.1177/ 0022185607087904

Pratsinakis, M., Hatziprokopiou, P., Grammatikas, D., \& Labrianidis, L. (2017). Crisis and the resurgence of emigration from Greece: Trends, representations, and the multiplicity of migrant trajectories. In B. Glorius \& J. Domínguez-Mujica (Eds.), European mobility in times of crisis: The new context of European southnorth migration (pp. 75-112). Bielefeld: J. Transcript Verlag.

Randstad Hellas (2019). Job advertisement by Randstad Hellas. Neuvoo. Retrieved from https://neuvoo.gr/ view/?id=ee4ce58d8235

RE/MAX. (2016). Pan-Hellenic survey of RE/MAX Hellas for real estate rentals in the year 2016. RE/MAX. Retrieved from https://www.remax.gr/news/382

RE/MAX. (2017). Pan-Hellenic survey of RE/MAX Hellas for real estate rentals in the year 2017. RE/MAX. Retrieved from https://www.remax.gr/news/439

RE/MAX. (2018). Pan-Hellenic survey of RE/MAX Hellas for real estate rentals in the year 2018. RE/MAX. Retrieved from https://www.remax.gr/news/485

Reichenberger, I. (2018). Digital nomads: A quest for holistic freedom in work and leisure. Annals of Leisure Research, 21(3), 364-380. https://doi.org/ 10.1080/11745398.2017.1358098

Richardson, R., \& Belt, V. (2001). Saved by the bell? Call centres and economic development in less favoured regions. Economic and Industrial Democracy, 22(1), 67-98. https://doi.org/10.1177/0143831X01221004

Richardson, R., Belt, V., \& Neil, M. (2000). Taking calls to Newcastle: The regional implications of the growth in call centres. Regional Studies, 24(4), 357-369. https://doi.org/10.1080/00343400050078132

Salvati, L., \& Benassi, F. (2020). Rise (and decline) of European migrants in Greece: Exploring spatial determinants of residential mobility (1988-2017), with special focus on older ages. Journal of International Migration and Integration. Advance online publication. https://doi.org/10.1007/s12134-020-00758-1

Sequera, J., \& Nofre, J. (2019). Touristification, transnational gentrification and urban change in Lisbon: The neighbourhood of Alfama. Urban Studies. Advance online publication. https://doi.org/10.1177/ 0042098019883734

Sigler, T., \& Wachsmuth, D. (2015). Transnational gentrification: Globalisation and neighbourhood change in Panama's Casco Antiguo. Urban Studies, 53(4), 705-722. https://doi.org/10.1177/0042098045168 070

Smith, H. (2016, May 28). Miracle in Athens as Greek tourism numbers keep growing. The Guardian. Retrieved from https://www.theguardian.com/ 
business/2016/may/28/greece-tourism-boomathens-jobs-growth

Tegan, L., Bergan, A., Gorman-Murray, E, \& Power, R. (2020). Co-living housing: Home cultures of precarity for the new creative class. Social \& Cultural Geography. https://doi.org/10.1080/14649365. 2020.1734230

Teleperformance. (2019). Blog. Teleperformance. Retrieved from https://jobsteleperformance.com/blog

Torkington, K. (2010). Defining lifestyle migration. Dos Algarves, 2010(19), 99-111.

Valentine, G. (2005). Tell me about...: Using interviews as a research methodology. In R. Flowerdew \& D. Martin (Eds.), Methods in human geography: A guide for students doing a research project (pp. 110-127). Harlow: Pearson Education.

van Noorloos, M., \& Steel, G. (2015). Lifestyle migration and socio-spatial segregation in the urban(izing) landscapes of Cuenca (Ecuador) and Guanacaste (Costa Rica). Habitat International, 54, 50-57. https://doi. org/10.1016/j.habitatint.2015.08.014

Wachsmuth, D., \& Weisler, A. (2018). Airbnb and the rent gap: Gentrification through the sharing economy. Environment and Planning A: Economy and Space, 50(6). https://doi.org/10.1177/0308518×18778038

Wachsmuth, D., Kerrigan, D., Chaney, D., \& Shillolo, A. (2017). Short-term cities: Airbnb's impact on Canadian housing market. Montreal: McGill School of Urban Planning.

Webhelp Greece. (2020). Webhelp Greece. Webhelp Greece. Retrieved from https://job.gr.webhelp.com/ Maps/WebHelp-Greece

Weiss, R. S. (1994). Learning from strangers: The art and method of qualitative interview studies. New York, NY: The Free Press.

Williams, A. M., \& Hall, C. M. (2000). Tourism and migration: New relationships between production and consumption. Tourism Geographies, 2(1), 5-27. https:// doi.org/10.1080/146166800363420

\section{About the Authors}

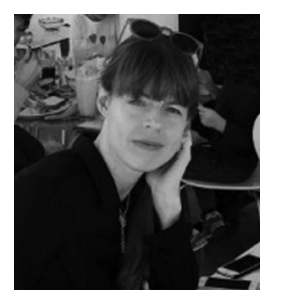

Johanna Lilius is a Post-Doctoral Researcher at the Department of Architecture, Aalto University, Finland. Her research has focused on housing and housing policy and development, (strategic) urban planning and development, suburban regeneration, urban cultures and lifestyles, as well as urban entrepreneurs. She is the author of Reclaiming Cities as Spaces of Middle Class Parenthood (Palgrave Macmillan).

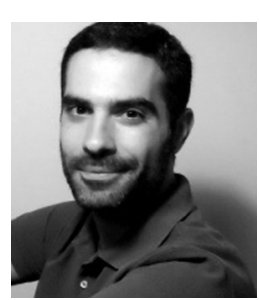

Dimitris Balampanidis holds a PhD in Urban Social Geography, an MSc in Urban and Regional Planning and a Diploma in Architecture. He is currently a Senior Researcher in the COHSMO Research Project (Horizon 2020) and is teaching Political Geography at the Geography Department at Harokopio University (Athens, Greece). His research focuses on access to housing, social and ethnic residential segregation, immigrants' integration and transcultural coexistence, socio-spatial inequalities and social inclusion, as well as on housing policies and urban and regional planning. 